\title{
Comparison of moss bag and native moss technique in monitoring airborne particulate and toxic elements
}

\author{
Nguyen Thi Minh Sang ${ }^{1}$, Le Hong Khiem², Nguyen An Son ${ }^{1}{ }^{\text {, }}$
}

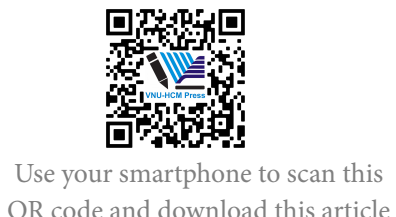

QR code and download this article

\begin{abstract}
Introduction: In Vietnam, the government has invested in monitoring stations in a few big cities like Hanoi and Ho Chi Minh City, which have transportation centers and industrial zones, to assess and predict levels of air pollution. However, the main disadvantage of installing monitoring stations is the cost of investment for operations, maintenance, and equipment. It is also time-consuming to collect and analyze the results. Therefore, it is generally not suitable for the country as a whole. Methods: Using mosses to monitor air quality brings qualitative and quantitative data with simple, environmentally-friendly economic methods. Mosses have particular biological characteristics that make them very suitable adsorbents for a wide variety of chemical elements. When used as transplants like moss bags, allow them to monitor a highly dense sampling network of any site easily. Mosses are bioindicators, plants with artificial roots. Results: In this study, moss bag and native moss were the two methods used to evaluate the accumulation of trace elements in air through Barbula Indica. Observations showed that both methods could detect the same elements: Al, Si, $\mathrm{P}, \mathrm{S}, \mathrm{Ca}, \mathrm{Ti}, \mathrm{V}, \mathrm{Cr}, \mathrm{Mn}, \mathrm{Fe}, \mathrm{Co}, \mathrm{Ni}, \mathrm{Cu}, \mathrm{Zn}, \mathrm{Br}, \mathrm{Rb}, \mathrm{Y}, \mathrm{Sb}, \mathrm{Ba}, \mathrm{Pb}$, and U. However, the accumulation of the elements in native moss is higher than in moss bag. The main reason is that the absorption efficiency of native moss in air-deposited elements is higher than in moss bags. Conclusion: Moss bags have been used most extensively and successfully in urban areas, where vegetation samples are either unobtainable or are poorly located to the source. These areas can lack moss, or the native moss simply does not grow during the dry season.
\end{abstract}

Key words: Air monitoring, air pollution, Barbula Indica, moss bag, native moss
${ }^{1}$ Dalat University, Dalat, Vietnam

${ }^{2}$ Institute of Physics of Vietnamese Academy of Science and Technology, Hanoi, Vietnam

\section{Correspondence}

Nguyen An Son, Dalat University, Dalat, Vietnam

Email: sonna@dlu.edu.vn

History

- Received: 2021-03-13

- Accepted: 2021-05-05

- Published: 2021-05-15

DOI : 10.32508/stdj.v24i2.2531

\section{Check for updates}

\section{Copyright}

(c) VNU-HCM Press. This is an openaccess article distributed under the terms of the Creative Commons Attribution 4.0 International license.

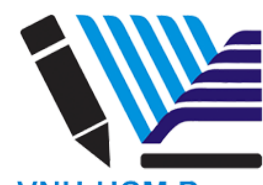

VNU-HCM Press

\section{INTRODUCTION}

Biomonitor represents a good solution for air quality monitoring. Vuković, et al. ${ }^{1}$ has shown that bioindicator monitoring is a simple and cost-effective method to evaluate pollutants in the atmosphere. Biomonitor organisms like lichens and moss can be considered bioindicators or bio accumulators.

The moss bag technique was introduced by Goodman and Roberts ${ }^{2}$. Since then, it has been a valuable technique for detecting airborne contaminants, such as heavy metals and nonmetals.

The moss bag technique is helpful in doing a detailed survey of polluted urban areas, where moss cannot grow naturally ${ }^{3}$. Moreover, this technique does not require maintenance or a source of electricity to continue operation. Another essential difference between the moss bag technique and instrumental measurements is sampling time ${ }^{4}$. Instrumental measurements are usually done in a short period, providing daily pollutant concentrations. On the other hand, Moss bags play a long-term role in the collection of statistical pollutants. Long-term sampling is a prerequisite for assessing the cumulative exposure to a given contaminant and its harmful effect on human health. Since 2014, Vietnam has participated in projects with European countries to investigate environmental pollution through metal deposition in the air. Together, they have developed research directions on air pollution on the moss indicator. Initially, works related to air pollution by the Barbula Indica technique were published $^{5-8}$.

In this study, two methods are used: native and moss bag. The method of detection is Total Reflection X-ray Fluorescence (TXRF), a multi-element analysis technique. It is used to determine qualitative and quantitative elements from the air in the town of Lac Duong.

\section{MATERIALS - METHODS}

\section{Sampling area}

Barbula Indica was used in native moss and moss bag. The time of the survey was from the beginning of November, 2020 to February, 2021. The research was conducted in Lac Duong, Lamdong, Vietnam.

Moss bag exposure was at 2 meters high, the same height as collected fresh moss. Table 1, and Figure 1 show the sampling area. 


\begin{tabular}{ccccc}
\multicolumn{2}{l}{ Table 1: The local moss samples network } & & \\
\hline No. & Sampling site & Place & Latitude & Longitude \\
\hline 1 & LD01 & Lac Duong & 12.003704 & 108.412293 \\
2 & LD02 & Top of Langbiang moutain & 12.046528 & 108.440146 \\
3 & LD03 & Langbiang tourist area & 12.020075 & 108.419331 \\
4 & LD04 & Strawbery farm, Lac Duong & 12.000362 & 108.434013 \\
5 & LD05 & Van Xuan - DT723 & 12.020963 & 108.443454 \\
\hline
\end{tabular}

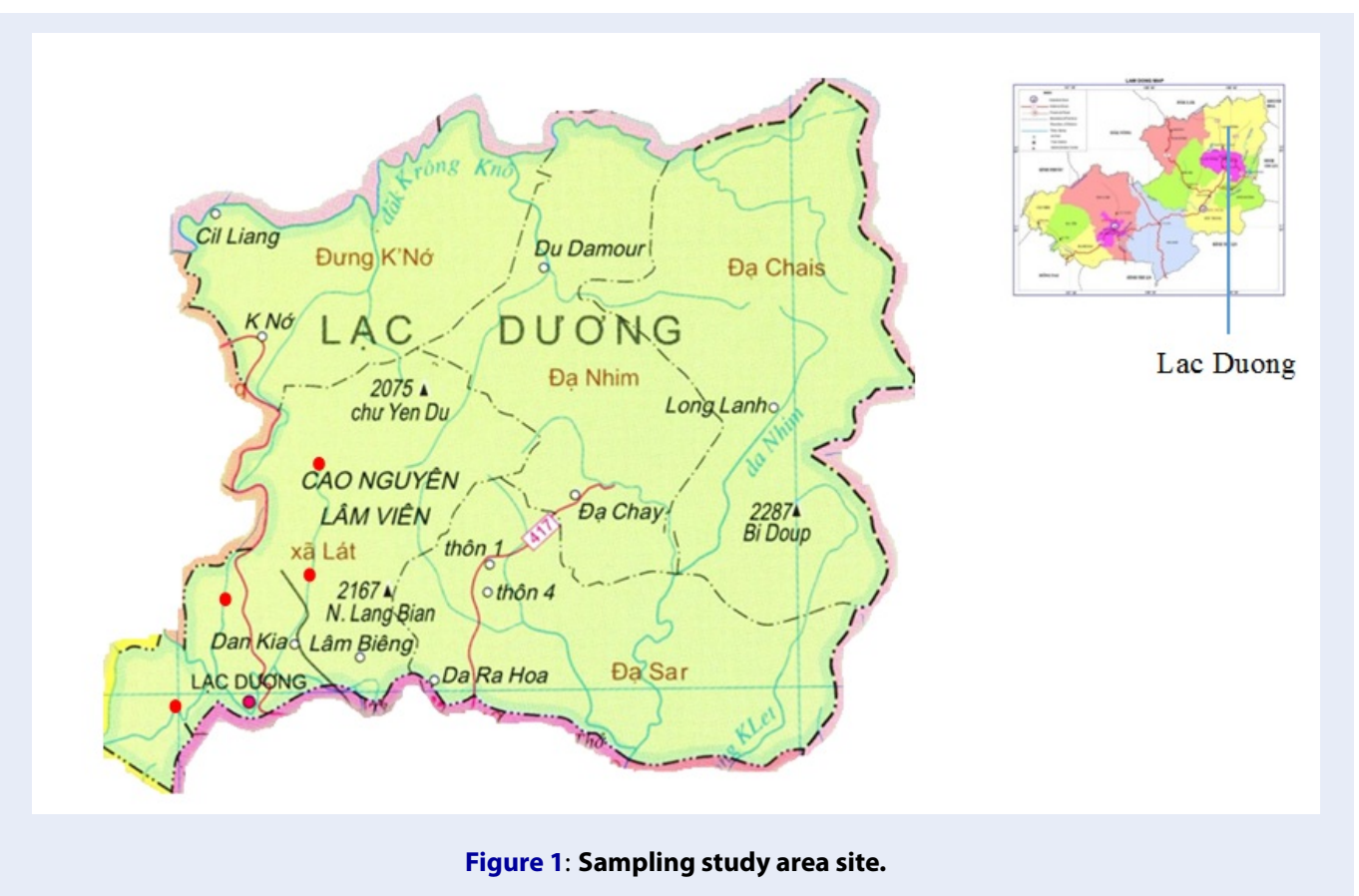

In this study, 5 sites in Lac Duong were selected to evaluate the effects of different possible pollution sources, specifically:

- Location LD01: the gateway to Lac Duong, which is adjacent to the tourist city of Da Lat. Here, many vehicles are travelling to the next popular tourist destination, the top of Langbian mountain.

- Location LD02: the peak of Langbian mountain, a famous tourist destination of Lac Duong, with an altitude of $2167 \mathrm{~m}$ above sea level. From this peak, one can evaluate the diffusion ability of chemical elements in the air in Lac Duong from different sources of pollution, such as agriculture and transportation.

- Location: LD03, the tourist area at the bottom of Langbian mountain, with many vehicles and a few brocade handicraft villages.
- Location LD04: a place of pure agricultural production, including high-tech farming and strawberry farms.

- Location LD05: a new, uninhabited, residential area.

\section{Native moss preparation}

After collection, only the green part of the moss is used for analysis. Therefore, Moss must be handled carefully, avoiding contamination from soil or rock, or other plants. In order to ensure the exact sampling location and minimize the external impact on the collected moss, it is necessary to prepare gloves and zip bags and use GPS to determine the location. Moss sampling points are selected according to pollution sources and clean areas, with a 3 to 5 kilometer distance between the nearest two sampling points. Moss samples are treated before being put into experimental measurements. The process of treating moss 


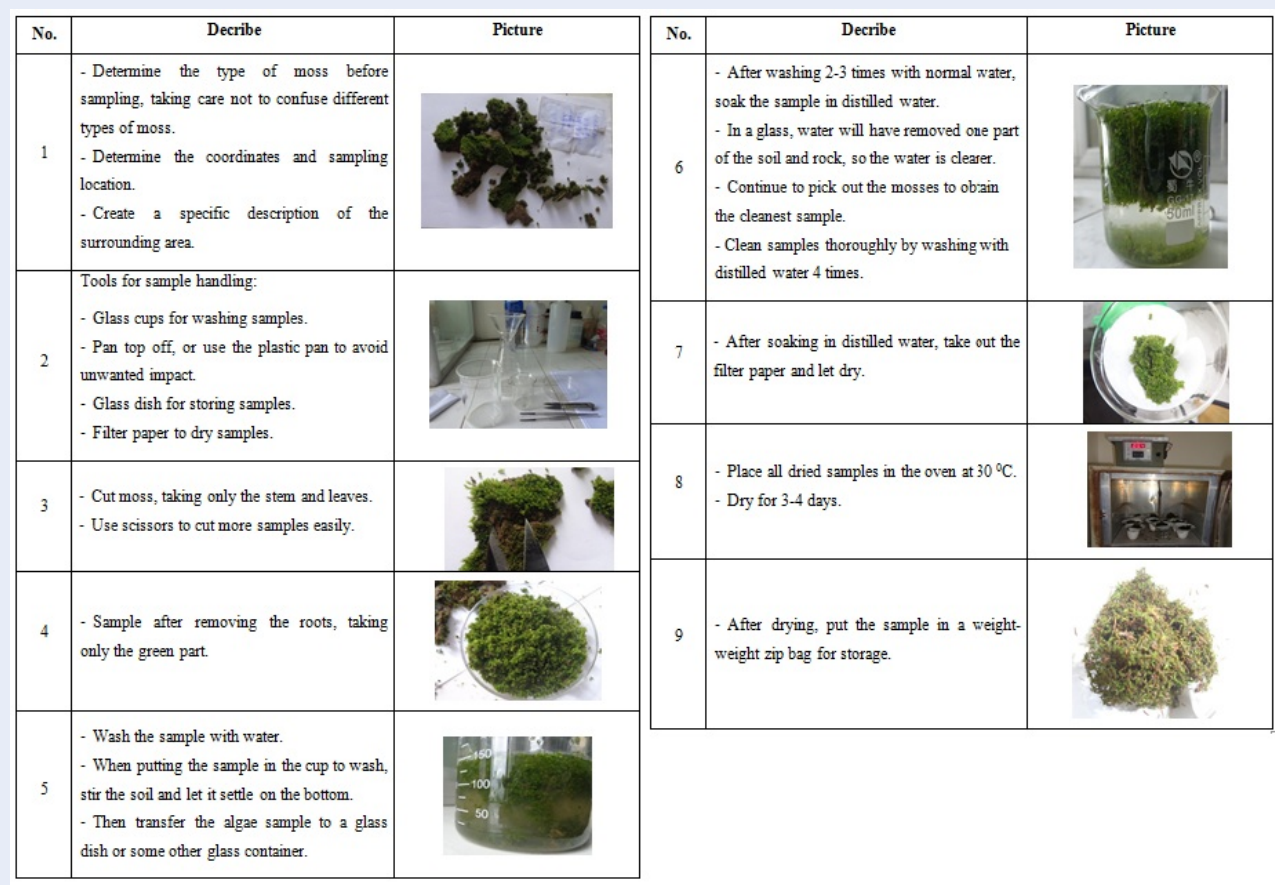

Figure 2: The process of sample treatment.

samples (from collection to drying) is shown below in Figure 2.

\section{Moss bag preparation}

The studies show that the selection of moss spices in the algae bag technique depends on the degree of deformation of the type of algae in the study area and the ability of the algae to absorb and adapt to pollution in that area ${ }^{9}$. The composition of the chemical elements in old shoots and young buds of moss is different ${ }^{10}$, and the absorption of the moss bags is also different from that of fresh ones ${ }^{11}$. In this study, Barbula Indica moss was selected as a biological indicator in a moss bag. The steps were as follows:

- First, Barbula Indica moss is chosen in a definite area, less affected by pollution, like moss in the mountains of Dung K'No, belonging to Bidoup Nui Ba National Park (Lam Dong, Vietnam). The location of collecting a moss sample has longitude 12.188447, latitude 108.463527. Many mosses are deep in the primary forest.

- After collecting the moss, perform the steps from 1 to 8 in Figure 3.

- Then, put and spear moss - natural moss collection samples in a bag.

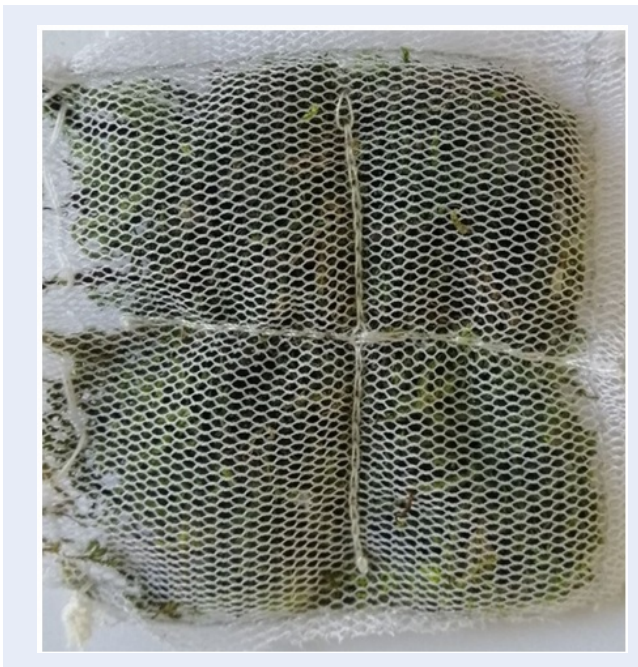

Figure 3: Moss bag.

\section{TXRF technique}

This study used a microwave digestion digester MARS 6 (Figure 4) to prepare samples in TXRF technique and homogenize the moss sample. The manipulations were carried out on the MARS 6 microwave digestion machine for moss samples: mix $0.5 \mathrm{~g}$ of the dried moss with $10 \mathrm{ml}$ of $\mathrm{HNO}_{3}$ (Merck) (65\%) it in the digestion flask. The digestion time includes 15 minutes for heat- 
ing to $220{ }^{\circ} \mathrm{C}, 25$ minutes for annealing, then natural cooling to room temperature. After finishing the microwave digestion, the moss was completely liquefied.

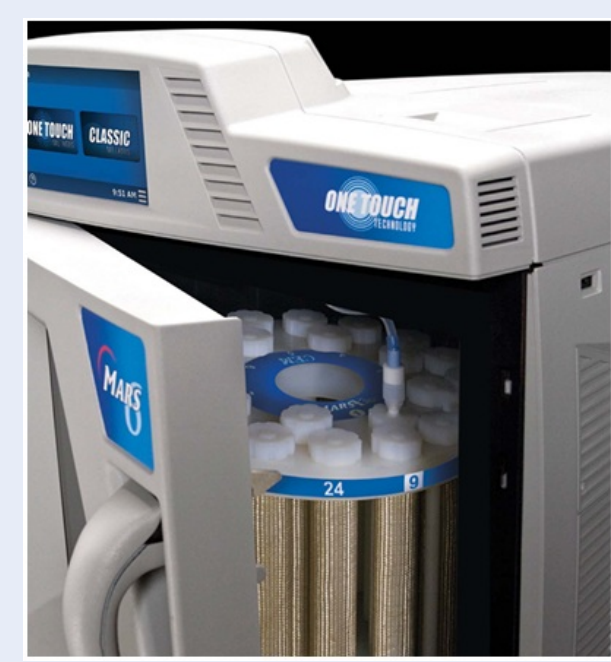

Figure 4: MARS 6 microwave digestion.

For analysis on TXRF, the liquefied moss requires an internal standard solution. In this study, the internal standard of Galium was used, with a concentration of 1 ppm.

To create a uniform surface for the sample, $10 \mu \mathrm{l}$ of silicone should be applied to the sample carrier (plate), then dried at $40{ }^{\circ} \mathrm{C}$ for 20 minutes. The specimen carrier used is a quartz glass disc, which has many advantages: high purity, low background, and easy cleaning $^{12}$. After the dish is dried, add $10 \mu \mathrm{l}$ of the sample solution to the measured center of the dish - the diameter of the drop should not exceed $10 \mathrm{~mm}$ - and continue to dry at $35^{\circ} \mathrm{C}$ for 40 minutes.

In addition to the size requirement for the diameter, the droplet, after being dripped onto the sample carrier and dried, must also satisfy the thickness requirement - namely, not to exceed $100 \mu \mathrm{m}$ (Figure 5).
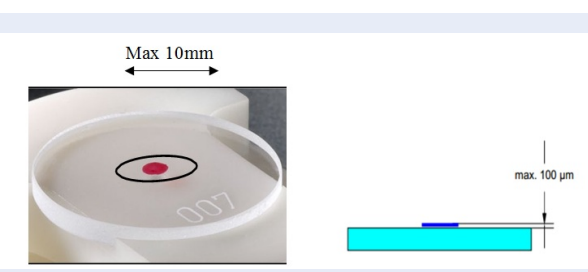

Figure 5: Maximum sample diameter and thickness.

After the sample preparation, continue to place the carriers' sample on the dryer to allow the sample to dry completely. The measuring system in the TXRF analysis is a S2 PICOFOX ${ }^{\mathrm{TM}}$ device. Steps to create moss samples for the TXRF measurement method can be shown in Figure 6.

\begin{tabular}{|l|l|l|}
\hline No. & \multicolumn{1}{|c|}{ Steps } & Picture \\
\hline 1 & $\begin{array}{l}\text { Pipette } 1.35 \mathrm{ml} \text { of homogeneous } \\
\text { moss sample solution into the } \\
\text { sample flask. }\end{array}$ & $\begin{array}{l}\text { Add } 0.15 \mathrm{ml} \text { of the intemal } \\
\text { standard Galium } 10 \mathrm{ppm} \text { together } \\
\text { with the moss sample. }\end{array}$ \\
\hline 3 & $\begin{array}{l}\text { Sample homogenizationwith the } \\
\text { intemal standard of Galium. }\end{array}$ \\
\hline 4 & $\begin{array}{l}\text { Drop } 10 \mu \mathrm{l} \text { of the sample onto a } \\
\text { quartz camier. }\end{array}$ \\
\hline 6 & $\begin{array}{l}\text { Put the test sample in the sample } \\
\text { changer cassette. }\end{array}$ \\
\hline
\end{tabular}

Figure 6: Steps to create moss samples for TXRF.

TXRF Type S2 PICOFOX ${ }^{\mathrm{TM}}$ is a semi-automatic analytical system, qualitative and quantitative analysis of multiple elements, detection threshold to $\mathrm{ppb}$ $(\mu \mathrm{g} / \mathrm{kg})$, wide-range analysis of elements from $\mathrm{Al}$ to U. Creation of the system includes: X-ray tube (Molipden target), emitted $17.5 \mathrm{keV}$ energy, working at a voltage of $50 \mathrm{kV}$, current of $1000 \mu \mathrm{A}$. The singlefunction filter is a multilayer crystal made of copper metal. X-ray acquisition detector is a semiconductor detector of SDD type. The system consists of the main components shown in Figure 7.

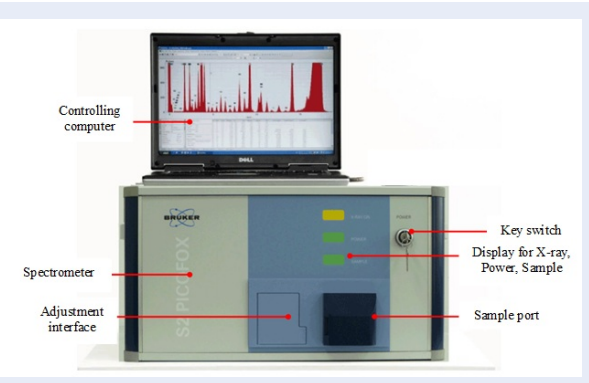

Figure 7: TXRF S2 PICOFOXTM spectrometer. 


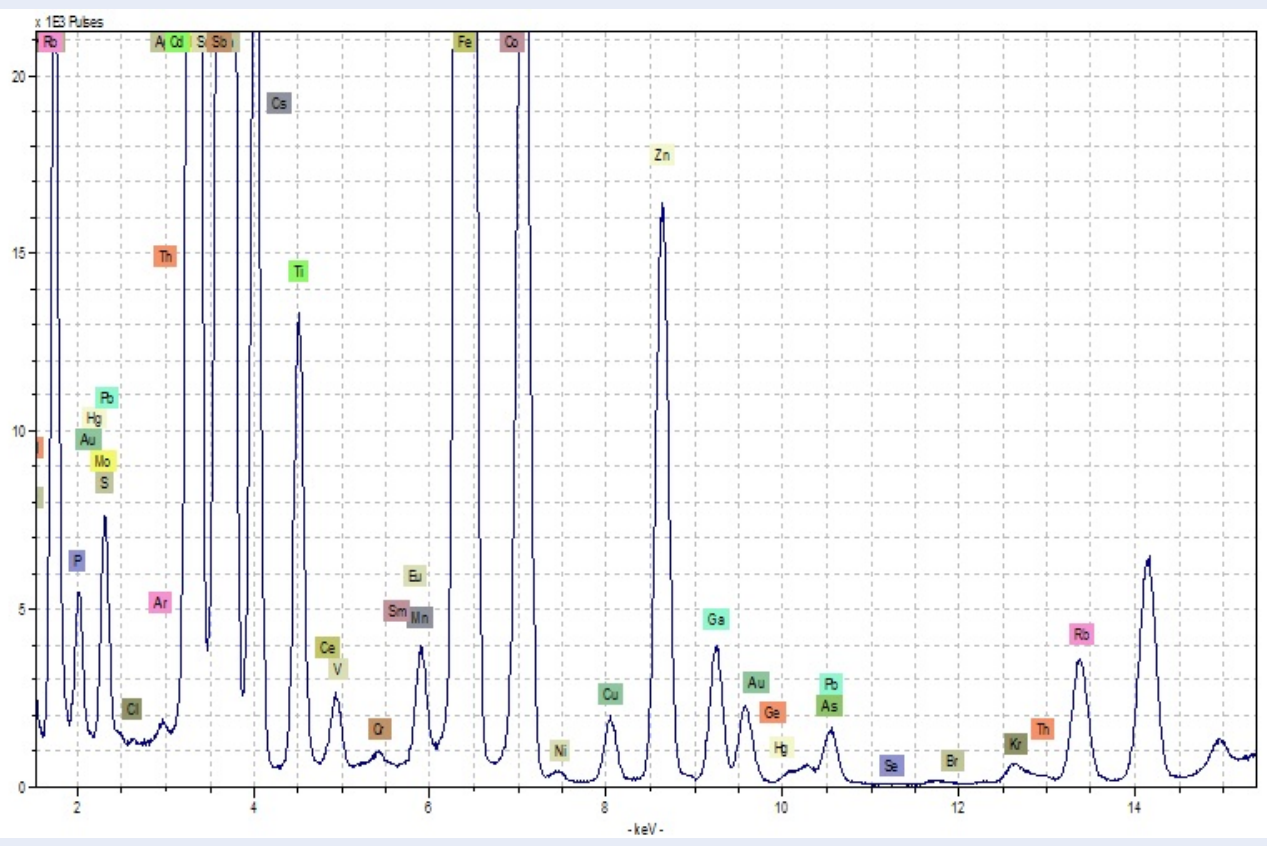

Figure 8: The TXRF spectrum pattern of moss samples.

\section{RESULTS}

TXRF measurement samples were conducted on an S2 PICOFOXTM spectrometer. The measuring time was 600 seconds per sample. The fit quality is a statistical parameter, which allows conclusions about the quality of the deconvolution. The standardized square sum of the differences between the measured and the calculated, deconvoluted intensities is calculated for all channels. Preferably, the value for the fit quality should be less than 10 . High values $(>10)$ indicate misidentified or non-identified elements respectively for an inaccurate gain correction. The following function is used to fit the following equation:

$$
\chi^{2}=\frac{1}{n_{2}-n_{1}} \sum_{i=n_{1}}^{n_{2}} \frac{1}{\delta_{i}^{2}}\left(y_{i+1}-y_{i}\right)^{2}
$$

where $n_{1}$ is the first channel of the peak $i$ (the left channel); $\mathrm{n}_{2}$ is the end channel of the peak $\mathrm{i}$ (the right channel); $\mathrm{y}_{i+1}$ the counts of channel $\mathrm{i}+1 ; \mathrm{y}_{i}$ the counts of channel i.

$$
\delta_{i}=\sqrt{N_{i}+2 N_{B G}}
$$

where $\delta_{i}$ is the standard deviation for the peak area; $\mathrm{N}_{i}$ is net peak area for the element $\mathrm{i} ; \mathrm{N}_{B G}$ is the background area.

The TXRF method has identified 21 elements, including $\mathrm{Al}, \mathrm{Si}, \mathrm{P}, \mathrm{S}, \mathrm{Ca}, \mathrm{Ti}, \mathrm{V}, \mathrm{Cr}, \mathrm{Mn}, \mathrm{Fe}, \mathrm{Co}, \mathrm{Ni}, \mathrm{Cu}, \mathrm{Zn}$, $\mathrm{Br}, \mathrm{Rb}, \mathrm{Y}, \mathrm{Sb}, \mathrm{Ba}, \mathrm{Pb}$, and U. Figure 5, Table 2 and Table 3 present the measurement results.

\section{DISCUSSION}

The chemical elements deposited in the air were conducted by two methods: native moss and active moss in Lac Duong town (Lam Dong Province). The results showed that:

- Using TXRF analyze system, both methods have similar chemical elements;

- For the most part, the concentrations of deposited elements in the air measured by the moss bag are much smaller than with the fresh one. This illustrates that the absorption efficiency of native moss in air-deposited elements is higher than in moss bag. However, the result also shows that some elements such as $\mathrm{Si}$, $\mathrm{Ca}, \mathrm{Cu}, \mathrm{Zn}, \mathrm{Br}$, and $\mathrm{U}$ detected by the moss bag technique have approximate values. Moreover, some of these values are slightly higher than using native moss methods. The reason for this is that elements from the earth's crust can influence these elements: the moss bag can be filled with dust from the street (elements $\mathrm{Si}, \mathrm{Ca}, \mathrm{U}$ ). The remaining elements can be evaporated from agrochemicals, such as fertilizers and pesticides (elements: $\mathrm{Cu}, \mathrm{Zn}, \mathrm{Br}$ );

- The concentration of elements deposited in the air in Lac Duong was compared with a previously published paper in Hanoi, Hochiminh, 
Table 2: The concentration of chemical elements in the native moss $(\mathrm{mg} / \mathrm{kg})$

\begin{tabular}{|c|c|c|c|c|c|c|c|c|c|c|c|c|}
\hline \multirow[t]{2}{*}{ No. } & \multirow{2}{*}{$\begin{array}{l}\text { Sam- } \\
\text { ple } \\
\text { Ele. }\end{array}$} & \multicolumn{2}{|l|}{ LD01 } & \multicolumn{2}{|l|}{ LD02 } & \multicolumn{2}{|l|}{ LD03 } & \multicolumn{2}{|l|}{ LD04 } & \multicolumn{2}{|l|}{ LD05 } & \multirow[t]{2}{*}{ Mean } \\
\hline & & Con. & $\pm \triangle$ & Con. & $\pm \triangle$ & Con. & $\pm \triangle$ & Con. & $\pm \triangle$ & Con. & $\pm \triangle$ & \\
\hline 1 & $\mathrm{Al}$ & 1837 & 74 & 1870 & 75 & 4031 & 161 & 1773 & 71 & 1442 & 58 & 2191 \\
\hline 2 & $\mathrm{Si}$ & 2825 & 113 & 4585 & 183 & 9970 & 399 & 4700 & 188 & 3698 & 148 & 5156 \\
\hline 3 & $\mathrm{P}$ & 287 & 12 & 922 & 37 & 738 & 30 & 520 & 21 & 531 & 21 & 600 \\
\hline 4 & S & 482 & 19 & 1216 & 49 & 1286 & 52 & 896 & 36 & 1090 & 44 & 994 \\
\hline 5 & $\mathrm{Ca}$ & 781 & 31 & 742 & 30 & 763 & 31 & 770 & 31 & 714 & 29 & 754 \\
\hline 6 & $\mathrm{Ti}$ & 107 & 4 & 122 & 5 & 194 & 8 & 206 & 8 & 105 & 4 & 147 \\
\hline 7 & V & 6.86 & 0.37 & 8.45 & 0.44 & 6.69 & 0.37 & 10.82 & 0.53 & 4.93 & 0.30 & 7.55 \\
\hline 8 & $\mathrm{Cr}$ & 5.19 & 0.31 & 5.37 & 0.31 & 10.38 & 0.52 & 11.18 & 0.55 & 5.10 & 0.30 & 7.44 \\
\hline 9 & $\mathrm{Mn}$ & 121.00 & 4.96 & 61.00 & 2.53 & 89.00 & 3.66 & 51.00 & 2.14 & 53.00 & 2.21 & 75.00 \\
\hline 10 & $\mathrm{Fe}$ & 3955 & 158 & 2400 & 96 & 4456 & 178 & 2565 & 103 & 1928 & 77 & 3061 \\
\hline 11 & Co & 1.39 & 0.16 & 0.70 & 0.13 & 1.24 & 0.15 & 0.57 & 0.12 & 0.58 & 0.12 & 0.90 \\
\hline 12 & $\mathrm{Ni}$ & 0.95 & 0.14 & 1.28 & 0.15 & 2.66 & 0.21 & 1.88 & 0.18 & 0.76 & 0.13 & 1.51 \\
\hline 13 & $\mathrm{Cu}$ & 10.86 & 0.53 & 10.51 & 0.52 & 14.33 & 0.67 & 5.95 & 0.34 & 9.49 & 0.48 & 10.23 \\
\hline 14 & $\mathrm{Zn}$ & 76 & 3 & 188 & 8 & 155 & 6 & 52 & 2 & 138 & 6 & 122 \\
\hline 15 & $\mathrm{Br}$ & 2.99 & 0.22 & 2.05 & 0.18 & 6.05 & 0.34 & 2.27 & 0.19 & 2.31 & 0.19 & 3.13 \\
\hline 16 & $\mathrm{Rb}$ & 24.11 & 1.06 & 6.86 & 0.37 & 15.66 & 0.73 & 16.90 & 0.78 & 12.23 & 0.59 & 15.15 \\
\hline 17 & Y & 24.82 & 1.09 & 1.13 & 0.15 & 1.72 & 0.17 & 6.93 & 0.38 & 0.69 & 0.13 & 7.06 \\
\hline 18 & $\mathrm{Sb}$ & 0.33 & 0.11 & 0.07 & 0.10 & 0.38 & 0.12 & 0.04 & 0.10 & 0.14 & 0.11 & 0.19 \\
\hline 19 & $\mathrm{Ba}$ & 2.22 & 0.19 & 23.39 & 1.04 & 20.05 & 0.90 & 3.17 & 0.23 & 21.44 & 0.96 & 14.05 \\
\hline 20 & $\mathrm{~Pb}$ & 4.77 & 0.29 & 5.49 & 0.32 & 6.81 & 0.37 & 4.68 & 0.29 & 2.83 & 0.21 & 4.92 \\
\hline 21 & U & 3.12 & 0.27 & 1.67 & 0.15 & 1.21 & 0.11 & 1.47 & 0.13 & 1.95 & 0.17 & 1.88 \\
\hline
\end{tabular}

Ele.: Elements

Con.: Concentration

Hoi An and Hue city (T. T. Doan Phan et al, 2018; Khiem L. H. et al., 2020). The results showed that the concentration of deposition elements is very low in Lac Duong, which is not affected much by traffic, agriculture and industry.

\section{CONCLUSION}

This study used moss bags and native moss to investigate the deposition of chemical elements in the air in Lac Duong town. The results of analysis by TXRF technique identified 21 elements. The results showed that the concentration of element deposition in the Lac Duong atmosphere was quite low compared to other studies in a few big cities in Vietnam.
This method can be applied through the moss bag technique when making biological observations to survey the air-deposited elements in the urban area - where there is a lack of native moss, or where native moss is difficult to grow. Because of low cost, this technique is also suitable for the assessment of air quality, regardless of environment, location, or topography. Additionally, it is very convenient to build environmental monitoring networks to have an overview of future environmental change.

\section{COMPETING INTERESTS}

The authors commit that they have no competing interests. 
Table 3: The concentration of chemical elements in the active moss $(\mathrm{mg} / \mathrm{kg})$

\begin{tabular}{|c|c|c|c|c|c|c|c|c|c|c|c|c|}
\hline \multirow[t]{2}{*}{ No. } & \multirow{2}{*}{$\begin{array}{c}\text { Sam- } \\
\text { ple } \\
\text { Ele. }\end{array}$} & \multicolumn{2}{|l|}{ LD01 } & \multicolumn{2}{|l|}{ LD02 } & \multicolumn{2}{|l|}{ LD03 } & \multicolumn{2}{|l|}{ LD04 } & \multicolumn{2}{|c|}{ LD05 } & \multirow[t]{2}{*}{ Mean } \\
\hline & & Con. & $\pm \triangle$ & Con. & $\pm \triangle$ & Con. & $\pm \triangle$ & Con. & $\pm \triangle$ & Con. & $\pm \triangle$ & \\
\hline 1 & $\mathrm{Al}$ & 1580 & 110 & 1613 & 113 & 3363 & 235 & 1327 & 93 & 1277 & 89 & 1832 \\
\hline 2 & $\mathrm{Si}$ & 2995 & 170 & 5335 & 276 & 10831 & 580 & 4522 & 245 & 4284 & 229 & 5593 \\
\hline 3 & $\mathrm{P}$ & 227 & 17 & 731 & 55 & 566 & 43 & 357 & 27 & 432 & 33 & 462 \\
\hline 4 & S & 448 & 29 & 1134 & 73 & 1160 & 75 & 725 & 47 & 1044 & 67 & 902 \\
\hline 5 & $\mathrm{Ca}$ & 843 & 47 & 804 & 45 & 799 & 44 & 723 & 40 & 794 & 44 & 793 \\
\hline 6 & $\mathrm{Ti}$ & 79 & 6 & 91 & 7 & 139 & 11 & 133 & 11 & 80 & 6 & 104 \\
\hline 7 & V & 4.64 & 0.41 & 5.73 & 0.51 & 4.39 & 0.39 & 6.36 & 0.56 & 3.43 & 0.30 & 4.91 \\
\hline 8 & $\mathrm{Cr}$ & 4.81 & 0.31 & 4.99 & 0.32 & 9.32 & 0.60 & 9.01 & 0.58 & 4.86 & 0.32 & 6.60 \\
\hline 9 & $\mathrm{Mn}$ & 106 & 7 & 54 & 4 & 76 & 5 & 39 & 3 & 48 & 3 & 65 \\
\hline 10 & $\mathrm{Fe}$ & 3000 & 237 & 1826 & 144 & 3279 & 259 & 1693 & 134 & 1506 & 119 & 2261 \\
\hline 11 & Co & 1.30 & 0.08 & 0.66 & 0.04 & 1.13 & 0.07 & 0.47 & 0.03 & 0.56 & 0.04 & 0.82 \\
\hline 12 & $\mathrm{Ni}$ & 0.83 & 0.06 & 1.13 & 0.08 & 2.27 & 0.15 & 1.44 & 0.10 & 0.69 & 0.05 & 1.27 \\
\hline 13 & $\mathrm{Cu}$ & 11.79 & 0.65 & 11.45 & 0.63 & 15.10 & 0.83 & 5.62 & 0.31 & 10.62 & 0.59 & 10.91 \\
\hline 14 & $\mathrm{Zn}$ & 81 & 5 & 200 & 11 & 159 & 9 & 48 & 3 & 151 & 9 & 128 \\
\hline 15 & $\mathrm{Br}$ & 3.55 & 0.18 & 2.44 & 0.12 & 6.98 & 0.35 & 2.35 & 0.12 & 2.83 & 0.14 & 3.63 \\
\hline 16 & $\mathrm{Rb}$ & 16.30 & 1.45 & 4.65 & 0.41 & 10.27 & 0.91 & 9.94 & 0.88 & 8.52 & 0.76 & 9.93 \\
\hline 17 & Y & 16.38 & 1.49 & 0.75 & 0.07 & 1.10 & 0.10 & 3.98 & 0.36 & 0.47 & 0.04 & 4.54 \\
\hline 18 & $\mathrm{Sb}$ & 0.18 & 0.02 & 0.04 & 0.00 & 0.20 & 0.02 & 0.02 & 0.00 & 0.08 & 0.01 & 0.10 \\
\hline 19 & $\mathrm{Ba}$ & 2.19 & 0.13 & 23.13 & 1.41 & 19.18 & 1.17 & 2.72 & 0.17 & 21.77 & 1.32 & 13.80 \\
\hline 20 & $\mathrm{~Pb}$ & 3.75 & 0.29 & 4.33 & 0.33 & 5.19 & 0.40 & 3.20 & 0.24 & 2.29 & 0.17 & 3.75 \\
\hline 21 & U & 3.39 & 0.19 & 1.82 & 0.10 & 1.27 & 0.07 & 1.39 & 0.08 & 2.18 & 0.12 & 2.01 \\
\hline
\end{tabular}

Ele.: Elements

Con.: Concentration

\section{ACKNOWLEDGEMENTS}

This research is supported by Dalat University under the project from 2021.

\section{AUTHORS CONTRIBUTIONS}

L. H. Khiem proposed the experimental plan, implemented the experiment. N. A. Son, N. T. M. Sang performed the experiments and literature review, compiled the data and manuscript preparation.

\section{REFERENCES}

1. Vuković G, Urošević MA, et al. Moss bag biomonitoring of airborne toxic element decrease on a small scale: A street study in Belgrade, Serbia. Science of the Total Environment. 2016;542:394-403. PMID: 26520264. Available from: https: //doi.org/10.1016/j.scitotenv.2015.10.091

2. Goodman TG, Roberts TM. Plants and soils as indicators of metals in the air. Nature. 1971;231:287-292. PMID: 4930976.
Available from: https://doi.org/10.1038/231287a0.

3. Kosior G, zka MC, et al. $\delta 34 \mathrm{~S}$ values and $\mathrm{S}$ concentrations in native and transplanted Pleurozium schreberi in a heavily industrialized area. Ecotoxicol. Environ. Saf. 2015;118:112117. PMID: 25919342. Available from: https://doi.org/10.1016/ j.ecoenv.2015.04.018.

4. Calabrese S, D'Alessandro W, et al. Characterization of the Etna volcanic emissions through an active biomonitoring technique (moss-bags): part 1 - major and trace element composition. Chemosphere. 2015;119:1447-1455. PMID: 25262949. Available from: https://doi.org/10.1016/j.chemosphere.2014. 08.086.

5. Viet HN. Relationship of Atmospheric Pollution Characterized by Gas (NO2) and Particles (PM10) to Microbial Communities Living in Bryophytes at Three Differently Polluted Sites (Rural, Urban, and Industrial) (2010). Microbial Ecology. 2010;59:24334. PMID: 19756850. Available from: https://doi.org/10.1007/ s00248-009-9580-2.

6. Phan TTD, et al. Study of airborne trace element pollution in central and southern Vietnam using moss (Barbula indica) technique and neutron activation analysis. Asia-Pacific Journal of Atmospheric Sciences. 2018;55(2):247-253. Available 
from: https://doi.org/10.1007/s13143-018-0065-4

7. Khiem LH. Assessment of atmospheric deposition of metals in Ha Noi using the moss bio-monitoring technique and proton induced X-ray emission. Journal of Radioanalytical and Nuclear Chemistry. 2020;324:43-54. Available from: https: //doi.org/10.1007/s10967-020-07066-z.

8. Son NA, Tien DPT, Khiem LH. Analysis Of Trace Element Atmospheric Deposition By Barbula Indica Moss At Baoloc Using The Total Reflection X-Ray Fluorescence Technique, Dalat University Journal Of Science. 2020;10(3):98-109.

9. Chakraborthy S, Paratkar GT. Biomonitoring of Trace Element Air Pollution Using Mosses. Aerosol and Air Quality Research. 2006;6(3):247-258. Available from: https://doi.org/10.4209/ aaqr.2006.09.0002.

10. Fernández JA, et al. Testing differences in methods of preparing moss samples. Effect of washing on Pseudoscleropodium purum. Environ. Monit. Assess. 2010;163:669-684. PMID: 19365610. Available from: https://doi.org/10.1007/s10661009-0867-z.

11. Adamo P, Giordano S, et al. Implementation of airborne trace element monitoring with devitalised transplants of Hypnum cupressiforme Hedw.: assessment of temporal trends and element contribution by vehicular traffic in Naples city. Environ. Pollut. 2011;159:1620-1628. PMID: 21420768. Available from: https://doi.org/10.1016/j.envpol.2011.02.047.

12. Bruker AXS Microanalysis. 2007;. 